\title{
Boosting Students' Writing Competency Using Writing Workshop
}

\author{
Rifky Dora Wijayati \\ Universitas Ahmad Dahlan Yogyakarta \\ rifky.dora@pbi.uad.ac.id
}

\begin{abstract}
This study explores the implementation of writing workshop towards beginner college students of Universitas Ahmad Dahlan. Writing workshop known as the instruction focuses on the goal of fostering lifelong writers and it is designed with different developmental and curricular needs. There are four principles of writing workshop, (1) students will write about their own lives, (2) students will use a consistent writing process, (3) students will work in authentic ways, (4) students will be able to encourage themselves in writing independently. The writing workshop may help students to find their "voice" in writing with less interference from the lecturer. Normally applied in elementary level, writing workshop is now adapted to be employed in higher education. It is become an important trail to facilitate the students in improving writing competency using continuous and integrated steps. This paper is an effort to share a down-to-earth idea of the implementation of writing workshop in higher education.

This study exploits quantitative methods using students' feedback as the data collection technique. A questionnaire was designed and distributed to 120 university students in English Education Departement at Universitas Ahmad Dahlan. Results revealed that students' feedback of the implementation of writing workshop in the class for improving their writing skills were generally positive. Through writing workshop, the writing process becomes more attractive for students. To the lecturers, act as a mentor author, modeling writing techniques and conferring with students as they move through the writing process perceptions give a diverse point of view in improving students' writing competency.
\end{abstract}

Keywords: writing, writing workshop, college students 


\section{A. Introduction}

The role of English as International Language (EIL) and as lingua franca (ELF) has been widely spread in many countries, especially in Indonesia, for instance, putting English as compulsory subject in junior and high school levels. Thus, it is used as introductory subject to be mastered as a tool for basic communication. In this phase, the use of English mainly focuses on mastering receptive skills. The receptive skills are the ways in which people extract meaning from the discourse they see or hear (AlJawi, 2010). Receptive skills cover listening and reading comprehension in which students receive the language and decode the meaning.

Meanwhile, in higher education, English is typically taught in universities in order to develop students' productive skills. Productive skills cover speaking and writing that are the manifestation of mastering the receptive skills. Both are used to produce a message through speech or written text. As the medium of communication, English teaching on higher education should be matched to the demand of globalization (Dardjowidjojo, 2002, cited in Zacharias, 2003). Teaching writing in higher education needs more effort and attempt to develop students' motivation. The 'voice' of students requires to be heard in order to grow writing as life long learning process. Therefore, a set of effective techniques is very essential to inspire students in learning writing.

In response, writing as one of the productive skill becomes essential way to deliver ideas, thoughts and messages to the world. In other words, teaching writing using appropiate techniques is necessary for students in higher education.

\section{B. Discussion}

\section{Characteristics of college students}

In broadest sense, higher students can be assumed as college students. In recent, most of college student is the product of postmodern times, where opinion and consumer interest have tended to have more impact on value formation and day to day decision making than "traditional values" including social values. According to Carson\&Lewis (2008) cited from Journal of College Reading and Learning, there are six characteristics of college students;

a. Need to understand the purpose and relevance of instructional activities.

b. Are both internally and externally motivated.

c. Have self-imposed cognitive barriers due to years of academic failure and lack self-confidence.

d. May have "shut down" in certain cognitive areas and will need to learn how to learn and overcome these barriers to learning. 
e. Want to establish immediate and long-term personal goals

f. Want to assume individual responsibility for learning and progress toward goals.

The characteristics above explains that college students have big possiblities to be successful learners. They tend to be very analytic, skeptic and ambitious. For them, learning is a process of gaining knowledge to be more skillful person, therefore, their contribution inside the class activities need to handled properly in order to create a joyful atmosphere.

\section{Writing workshop}

Writing as one of the productive skills, counts as the most difficult skill to be mastered among the other skills. According to Richards and Renandya (2002), there is no doubt that writing is the most difficult skill for students to master. The difficulty lies not only in generating and organizing ideas, but also in translating these ideas into readable text. The skills involved in writing are highly complex. The students have to pay attention to higher level skills of planning and organizing as well as lower level skills of spelling, punctuation, word choice, and so on.

Furthermore, Olshtain (2001) states writing in addition to being a communicative skill of vital importance, is a skill which enables the student to plan and rethink the communication process. It therefore provides the student with the opportunity to focus on both linguistic accuracy and content organization (p.231). We have to form priorities and weight the elements according to students' needs and teachers' own philosophy.

Moreover, writing workshop is one of the ways in learning writing which is designed on how to write in specific forms. Writing workshop is an instructional model that views writing as an ongoing process in which students follow a given set of procedures for planning, drafting, revising, editing, and publishing their writing (Calkins, 1986). It allows students to be at various stages of the writing process at one time. In general, writing workshop applies in elementary level.

Then, the researcher tries to adopt the model of writing workshop to be applied in higher education. The focus of this model is collaboration with peers and lecturer in which process writing focuses primarily on what students want to communicate. Here, students have a large amount of choice in their topic and style of writing. The teacher acts as a mentor author, modeling writing techniques and conferring with students as they move through the writing process. The process of writing workshop is defined as follow, 
Table 1.

\begin{tabular}{|l|l|}
\hline Mini Lesson & $\begin{array}{l}\text { A short lesson focused on a } \\
\text { single topic } \\
\text { that students need help with. }\end{array}$ \\
\hline Status of the class & $\begin{array}{l}\text { A quick way of finding out what } \\
\text { each } \\
\text { student is working on. }\end{array}$ \\
\hline Writing Time & $\begin{array}{l}\text { They write. You can write and/or } \\
\text { conference with individual } \\
\text { students or small groups }\end{array}$ \\
\hline Sharing & $\begin{array}{l}\text { Writers read what they have } \\
\text { written and seek feedback from } \\
\text { their audience. You can share } \\
\text { your writing, too }\end{array}$ \\
\hline
\end{tabular}

The process above enables lecturer to directly address the needs of students who struggle with the conventions of English in their writing. Peer help with revising and editing can also be beneficial.

In either case, concerns about correctness should not supercede the students' need to communicate. Writing needs to be taught as a process, with the emphasis on idea generation and drafting before revision and editing. Encouraging students to write from what they know, for real purposes, and from interest is an important part of this process.

In line with the process of writing workshop, the principles also allow students to share their ideas, toughts and voice during the implementation. First principle is that the students will write about their own lives which prompt them to choose what they know and what they like best. Secondly, students will use a consistent writing process because their friends and lecturer are able to give feedback on their writing. Thirdly, students will work in authentic ways, means, they search every possibility to develop their writing system through sharing from their actual environment. Lastly, students will be able to encourage themselves in writing independently wherein after long process they will work confidently as a writer.

\section{Result of Writing Workshop Implementation}

The researcher have distributed 120 questionnaires to the English Education students of Universitas Ahmad Dahlan. The students were on four different classes. All of them joined Paragraph Writing Course in the second semester. During the semester, I, as their lecturer, have applied writing workshop for 9 
meetings ( 5 meetings before mid-term test and 4 meetings before final examination). The list of the questions delivered as follow;

Table 2.

\begin{tabular}{|c|c|}
\hline $\begin{array}{l}\text { Section I } \\
\text { (answered by their } \\
\text { statements) }\end{array}$ & $\begin{array}{l}\text { a. Asking for personal background } \\
\text { b. Asking for how long they have been } \\
\text { learning English } \\
\text { c. Asking for how many times they do } \\
\text { writing in a week }\end{array}$ \\
\hline $\begin{array}{l}\text { Section II } \\
\text { (answered by giving } \\
\text { circle to the numbers } \\
\text { given. } \\
\text { 1. Very useful } \\
\text { 2. Sometimes } \\
\text { useful } \\
\text { 3. Rarely useful } \\
\text { 4. Useless } \\
\text { 5. Unsure }\end{array}$ & $\begin{array}{l}\text { a. How useful is the written feedback } \\
\text { that you receive from your lecturer on } \\
\text { your paragraph writing? } \\
\text { b. How useful is the written feedback } \\
\text { that you receive from your friends on } \\
\text { your paragraph writing? } \\
\text { c. How useful is the process of sharing } \\
\text { that you receive from your lecturer or } \\
\text { friends on your paragraph writing? }\end{array}$ \\
\hline $\begin{array}{l}\text { Section III } \\
\text { (answered by giving } \\
\text { circle to the numbers } \\
\text { given. } \\
\text { 1. Very useful } \\
\text { 2. Sometimes } \\
\text { useful } \\
\text { 3. Rarely useful } \\
\text { 4. Useless } \\
\text { 5. Unsure }\end{array}$ & $\begin{array}{l}\text { a. I am satisfied with my teacher's } \\
\text { feedback on my paragraph. } \\
\text { b. I prefer my classmates to give me } \\
\text { feedback on my paragraph and not the } \\
\text { teacher. } \\
\text { c. I prefer my teacher to give me oral } \\
\text { rather than written feedback on my } \\
\text { essays. } \\
\text { d. I like it when the teacher corrects all } \\
\text { my errors. } \\
\text { e. I like it when the teacher corrects only } \\
\text { the most serious errors I make in my } \\
\text { paragraph. } \\
\text { f. I prefer my teacher not to correct my } \\
\text { errors but just to indicate them and } \\
\text { ask me to correct them myself. } \\
\text { g. I like it when the teacher uses codes } \\
\text { or symbols to help me with the nature } \\
\text { of my errors. } \\
\text { h. It would be better if the teacher made } \\
\text { some verbal comments instead of } \\
\text { using codes or symbols to identify my } \\
\text { errors. } \\
\text { i. It would be better if the teacher did } \\
\text { not correct or indicate any of my } \\
\text { errors and just made some general } \\
\text { comments. }\end{array}$ \\
\hline
\end{tabular}




\begin{tabular}{|c|c|}
\hline & $\begin{array}{l}\text { j. The mark I get is more important than } \\
\text { my teacher's corrections and } \\
\text { comments on my paragraph. }\end{array}$ \\
\hline $\begin{array}{l}\text { Section IV } \\
\text { (answered by giving } \\
\text { circle to the numbers } \\
\text { given. } \\
\text { 1. Very important } \\
\text { 2. Fairly important } \\
\text { 3. Not very } \\
\text { important } \\
\text { 4. Unimportant }\end{array}$ & $\begin{array}{l}\text { - How important it is for you to receive } \\
\text { feedback on the following aspects of } \\
\text { your writing? } \\
\text { a. Grammar } \\
\text { b. Organization } \\
\text { c. Vocabulary } \\
\text { d. Content } \\
\text { e. Mechanics }\end{array}$ \\
\hline $\begin{array}{l}\text { Section V } \\
\text { (answered by their } \\
\text { statements) }\end{array}$ & $\begin{array}{l}\text { - When you take your paragraphs back } \\
\text { how often do you pay attention to all } \\
\text { lecturer's / friends' feedback? } \\
\text { - When you get your compositions back } \\
\text { how often do you.. } \\
\text { a. rewrite them according to lecturer's } \\
\text { feedback? } \\
\text { b. discuss the most common errors in } \\
\text { the classroom? } \\
\text { c. correct your own errors in the } \\
\text { classroom? } \\
\text { d. keep notes of you errors together } \\
\text { with the correct forms? }\end{array}$ \\
\hline
\end{tabular}

From the questionnaires above, students were responded actively. In section I, 53,78\% students like to write three times a week. They write on their diaries and do assignment. 27,81\% students never write because they prefer to do reading. The rest of them $18,41 \%$ students rarely do writing.

Table 3. Result of Section II
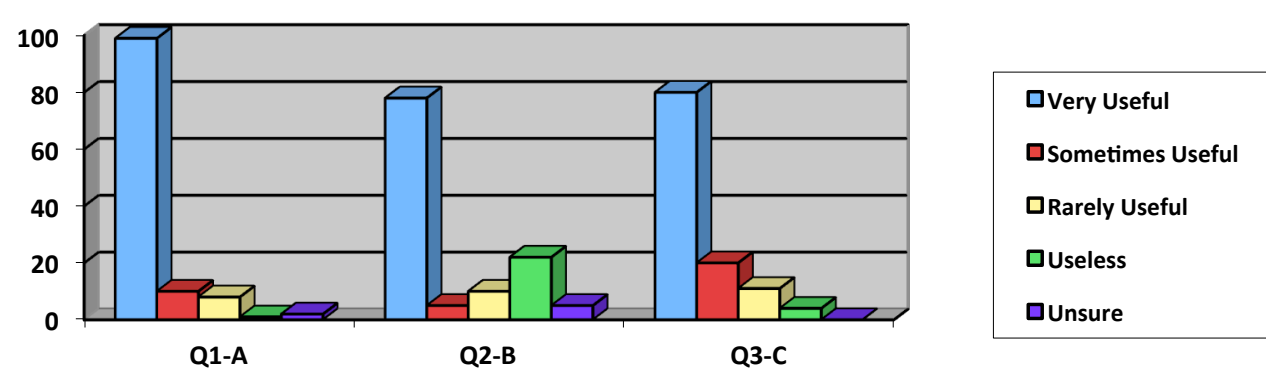

The chart above shows the importance of feedback and sharing process during writing workshop. Most of students feels that 
lecturer and their friends provide useful information for their writing process. Therefore, in section III, the level of possibility in building writing through authentic ways resulted postive feedback from the students. They were able to brainstorm, develop and construct the topic and its content in their paragraph. The students were also able to choose the significance feedback they likely most for them.

Table 4. Result of Section III

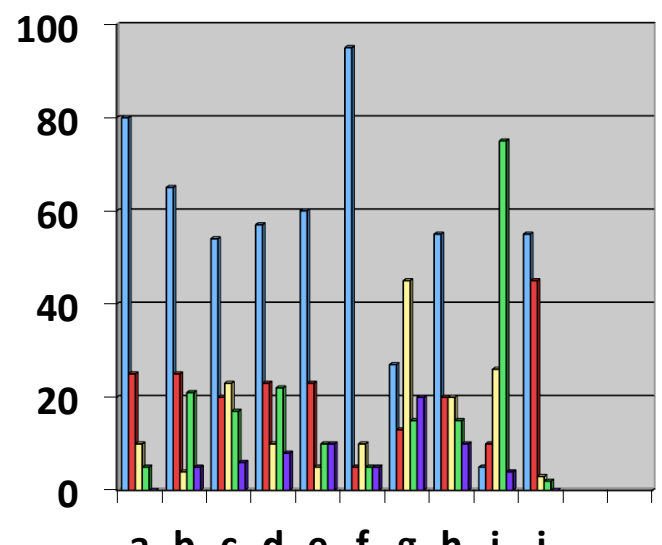

\begin{tabular}{|l|}
\hline$\square$ Very Useful \\
$\square$ Sometimes Useful \\
$\square$ Rarely Useful \\
$\square$ Useless \\
$\square$ Unsure \\
\hline
\end{tabular}

Moreover, in section IV, students chose that receiving feedback on few aspects of your writing like grammar, organization, vocabulary, content and mechanics of the paragraph are considered important in order to develop their writing system.

Table 5. Result of Section IV

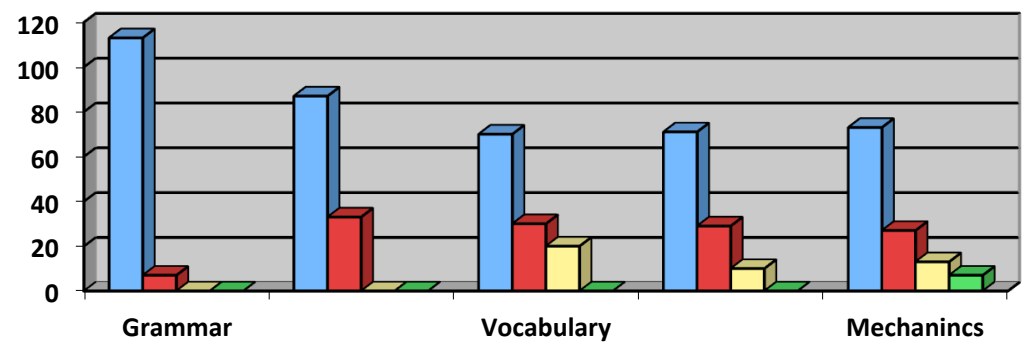

QVery important

口Fairly important

DNot very important

口Unimportant

Lastly, students' response to the feedback and their actions in revising the paragraphs were assumed positive. Most of them tried to rewrite the paragraph from the feedback given by discussing the common errors with their students. They also rarely corrected errors individually, however, students always keep notes together with the correct forms. 
Table 6. Result of Section $V$

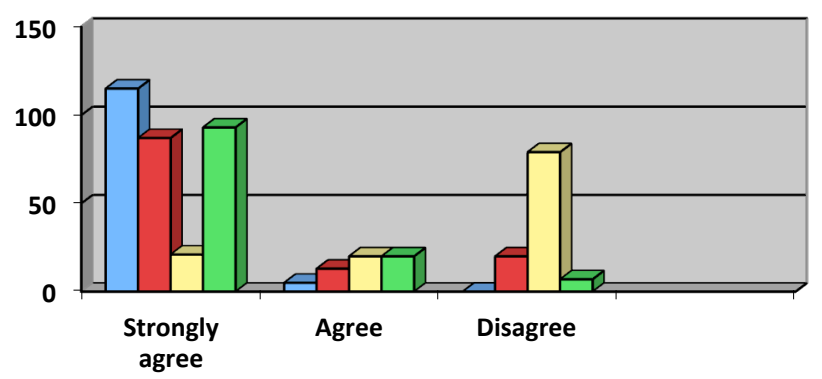

口rewrite the paragraph

Ddiscuss it with friends

asometimes do own correction in the classroom

$\square$ keep notes

In addition, from the questionnares have delivered to the students, they feel that sharing ideas, thought and working together as group or individually in writing workshop bestowed opportunity to build their writing competency.

\section{Conclusion}

As it told in the famous proverb that experience is the best teacher. The implementation of writing workshop for college students as a tool of lifelong learning is beneficially trusted to boost their writing competency. The model of writing workshop offers students to be more freely during the process of writing. Sharing activities between the lecturer-students and students-students may grow mutual understanding on how they become confident writer. Furthermore, through writing workshop, the writing process becomes more attractive for students and lecturer plays his/her best role as their mentor in this model. It is concluded that students' have positive feedback of the implementation of writing workshop in the class for improving their writing.

\section{References}

Al-Jawi, D. F. (2010). Teaching The Receptive Skills. Egypt: Umm Al-Qura University.

Calkins, L. M. (1986). The Art of Teaching Writing. United Kingdom: Heinemann.

Carson, B., \& Lewis, G. (2008). Being Successful in College. New York: Mc Graw - Hill Companies.

Olshtain, E. (2001). Functional tasks for mastering the mechanics of writing and going just beyond. In Celce-Murcia (Ed), Teaching English as a second or foreign language (pp.207-217). Boston: Heinle \& Heinle

Richard, J. C., \& Renandya, W. (2002). Methodology in Language Teaching: An Anthology of Current Practice. Cambridge: Cambridge University Press. 